\title{
Savings-Growth Nexus in Ghana: Cointegration and Causal Relationship Analyses
}

\author{
Robert Becker Pickson ${ }^{1}$, Koduah Dawud Enning' ${ }^{2}$ Anthony Siaw ${ }^{1}$ \\ ${ }^{1}$ College of Economics and Management, Sichuan Agricultural University, Chengdu, China \\ ${ }^{2}$ Research, Monitoring and Evaluation Department, Ghana Cocoa Board, Accra, Ghana \\ Email: myselfpickson@yahoo.com
}

How to cite this paper: Pickson, R.B. Enning, K.D. and Siaw, A. (2017) SavingsGrowth Nexus in Ghana: Cointegration and Causal Relationship Analyses. Theoretical Economics Letters, 7, 139-153. https://doi.org/10.4236/tel.2017.72012

Received: October 4, 2016

Accepted: February 1, 2017

Published: February 4, 2017

Copyright (c) 2017 by authors and Scientific Research Publishing Inc. This work is licensed under the Creative Commons Attribution International License (CC BY 4.0).

http://creativecommons.org/licenses/by/4.0/

\section{Open Access}

\begin{abstract}
The wide range of controversies surrounding the direction of causality between savings and economic growth necessitated this study. The study was intended to investigate the relationship between gross domestic savings and economic growth in Ghana; with the specific objective of finding whether there exists a long run relationship between them, and it was also intended to ascertain the direction of causality between the two running actors in the study over the period of 1972 to 2013. The study employed Johansen cointegration test to reveal no long run relationship between gross domestic savings and economic growth in Ghana. This necessitated the usage of the VAR technique to estimate the short run relationships. The finding was that there exists a unidirectional line of causation running from gross domestic savings to economic growth in Ghana. It is strongly recommended therefore that the Bank of Ghana will use the monetary policy instruments to influence and advise the commercial banks on the need to peg the deposit rate relatively higher at least equal or little above the existing interest rate. This is because the deposit rate is the opportunity cost of money demand for other purposes.
\end{abstract}

\section{Keywords}

Gross Domestic Savings, Economic Growth, Ghana

\section{Introduction}

The dynamic relationship between savings and economic growth among developing economies continues to receive significant empirical attention in the ever growing literature. The role of savings in capital accumulation in realizing growth in output per capita was highlighted in the Solow-Swan [1] and Romer [2] growth models. They clarified the integral role played by savings in raising the steady state output per capita as well as the growth rate of output per capita. 
Romer [2] explicitly showed that higher rates of savings and hence capital accumulation can trigger a permanent increase in economic growth. Some empirical studies such as Jappelli and Pagano [3], Carroll and Weil [4], Sinha and Sinha [5], Carroll et al. [6], and Rodrik [7] claimed that there is a positive causal relationship which runs from economic growth to savings. However, other studies conducted by Lewis [8]; Levine and Renelt [9]; Mankiw et al. [10]; Alguacil et al. [11], and Sajid and Sarfraz [12] favoured the capital fundamentalists who believe that savings cause economic growth. Shahbaz and Khan [13] empirically threw their weight behind capital fundamentalists by suggesting that the direction of causality runs from savings to economic growth. They believed that capital accumulation through savings will translate positively into investment and hence sustainable economic growth in the long run.

In fact, economic theories and empirical studies having established the line of causation between savings and economic growth, the question about this causality is, to what degree? The questions about the degree of responsiveness of economic growth as a result of an increase in gross domestic savings and how significant it is, still beg for empirical answers. According to Ogoe [14], the past and recent governments, economic policy-makers and other stakeholders in the Ghanaian economy are aware of the positive association between gross domestic savings and economic growth on the basis of economic theories, but oblivious of the angle of causality between them. Therefore, the direction of favourable economic policy and programmes over the years intended to ameliorate the growth of these two variables have been misplaced. At the same time, as there exists a correlation between savings and growth, the question of the way the direction of causality runs for Ghana has received little empirical academic address.

With the intention of providing answers to these mind-boggling questions of the degree of responsiveness of economic growth to changes in gross domestic savings, this paper seeks to determine whether there exists a long run relationship between gross domestic savings and economic growth. Finally, this paper attempts to examine the direction of causation between gross domestic savings and economic growth in Ghana.

\section{Review of Related Literature}

Generally speaking, the empirical literature on examining the relationship between savings and economic growth yield inconclusive evidence. On one hand, savings cause economic growth and the other hand, the reverse is true. Empirical works that are closest to the study with respect to the issue of causality and methodology have been discussed. These empirical verifications are mostly dependent on the macroeconomic settings and foundations of those countries in which the study are done.

Deaton and Paxson [15] used household data from Taiwan and Thailand to examine the economic growth and savings nexus among individuals and households. They found out that changes in the rate of economic growth in some circumstances have large effects on the aggregate savings rate but the size and sign 
of these effects depend on the rate of economic growth and the rate of population growth, and in many cases, the effect of growth on savings is small.

Mohan [16] used time series annual data and Granger-causality test to determine the relationship between economic growth and domestic savings for various economies with different income levels. He decomposed the income classes into four groups, namely low-income (LIC), low-middle income (LMC), uppermiddle income (UMC) and high-income countries (HIC). The primary hypothesis of the study was whether or not the income levels of the economy influence the direction of causality between economic growth rate and savings. Based on the empirical results, he found out that in the low-income countries (LICs), the results were mixed, in the low-middle income countries (LMCs), the direction of causality moves from economic growth rate to growth rate of savings. In the high-income countries (HICs) except in Singapore where the causality moves from economic growth rate to growth rate of savings, but a bi-directional causality is more prevalent in the upper-middle income countries (UCMs).

With the aid of a time series quarterly data in Pakistan, Sajid and Sarfraz [12] investigated the causal relationship between savings and economic growth using the vector error correction technique and the cointegration. They found a unidirectional short-run causality from gross national product (GNP) to both national and domestic savings. This result vindicates Keynesian point of view that savings depend on output level. However, there is a unidirectional long run causality from public savings to output (GNP and GDP) with savings being characterised by a higher speed of adjustment compared to output. This long run results favour the capital fundamentalists' viewpoint that output depends on savings.

A similar study by Khan and Shahbaz [13], used Autoregressive Distributed Lag model (ARDL) Bounds test and Johansen cointegration to examine the long run association between savings and economic growth in Pakistan. Their results finally revealed the existence of a long run relationship between domestic savings and economic growth. The authors also found a one-way causality running from economic growth to domestic savings in Pakistan.

In China, Lean and Song [17] also subjected the saving growth and economic growth relationship to a thorough examination. They used five research samples in their study; the country itself and four representatives provinces, these are Beijing, Shanghai, Guizhou and Xinjiang. They found China's economic growth to be cointegrated with the other two variables, namely the household saving and enterprise saving growth. They found also that beside Shanghai, between household saving and economic growth in the short run, but a unidirectional causality exists from the economic growth to the enterprise saving growth for all samples in the long run.

The nexus between economic growth and domestic savings literature on Ghana is limited despite the growing interest of researchers and policymakers in the subject. Ogoe [14] used annual data spanning the period 1961 to 2008 to examine the long run and causal relationships between gross domestic savings and 
economic growth in Ghana. The author employed the Engel-Granger cointegration test technique and the Vector Autoregressive (VAR) model to assess the long run and causal relationships respectively. No relationship was found to exist between the two running actors in the long run. A bi-directional line of causation was found to exist between gross domestic savings and economic growth in Ghana.

Johansen cointegration technique and the Granger causality test were employed by Abu [18] to analyse the relationship that exists between savings and economic growth in Nigeria between the periods of 1970 to 2007. The results revealed the existence of a long run relationship between savings and economic growth in Nigeria. The author indicated that economic growth Granger causes savings in Nigeria. Subsequently, the study provided solid grounds to back the Keynesian theory, which explicitly asserts that it is economic growth that triggers savings but not the reverse.

In addition, Bankole and Fatai [19] attempted to use Granger causality and Engle-Granger cointegration tests to examine the causal and effect relationship between the domestic savings and economic growth in Nigeria for the period of 1980-2010. It was revealed that there is a unidirectional running from savings to economic growth in Nigeria. As a result, the study supports the Solow's hypothesis that savings precede economic growth but refuses the Keynesian theory that it is economic growth that leads to higher savings.

On the other hand, Adeleke [20] used annual data over the period 1970-2013 via ARDL bounds testing approach to cointegration and error correction model (ECM) for dynamics to examine the saving-growth nexus in Nigeria. The study found that there exists a bi-directional causality between savings and economic growth in Nigeria such that both Keynes and Solow models are relevant and workable in Nigeria.

Alomar [21] investigated the relationship between domestic savings and economic growth using annual time series data with the aid of the cointegration techniques. He found out that economic growth Granger causes growth rate of savings in four countries, Bahrain, Kuwait, Qatar and Saudi Arabia. In Bahrain only, a bi-directional causality was found and concluded that income source of a country does play an important role in determining the direction of causality. In the countries where most incomes come from natural resources, direction causality is from economic growth to domestic savings. Also, El-Seoud [22] adopted Granger causality test to reveal a significant bilateral causality between private savings and economic growth in Bahrain.

In the case of South Africa, Odhiambo [23] used an error-correction based causality test technique to examine the direction of causality in a trivariate model of savings growth rate, economic growth, and foreign capital inflow over the period of 1950 to 2005 . The study indicated that, in the short run, there is a bi-directional causality between savings rate and economic growth. The author also showed a bi-directional causality between savings and foreign capital inflow, but found a unidirectional causality running from economic growth to foreign 
capital inflow.

Sothan [24] determined the direction of causality between saving and economic growth in Cambodia, using data for the period 1989-2012. His empirical analysis was based on Granger causality test. It was found that domestic saving does not Granger cause economic growth which contradicts the conventional wisdom that causality moves from savings to economic growth. The study further revealed that there is no causality from economic growth to saving. In effect, economic growth and saving are independent of each other in Cambodia.

\section{Econometric Methodology}

\subsection{Model Specification}

The relationship between savings and economic growth has been modeled in many empirical research works (see Sinha and Sinha [5], Japalli and Pagano [3], Saltz [25], and Ogoe [14]). The econometric model that the study employed theoretically follows the Keynesian model and the Solow hypothesis. For instance, the Keynesian model states that increase in income leads to a growth in savings. This is mathematically stated as savings as a function of income (output). Thus;

$$
\mathrm{GDS}_{t}=\alpha_{0}+\alpha_{1} \mathrm{GDP}_{t}
$$

The study transformed Equation (1) into logarithmic form to overcome the possibility of the problem of heteroskedasticity in the residual of the estimated model. Therefore, Keynesian model is econometrically specified as;

$$
\ln \mathrm{GDS}_{t}=\alpha_{0}+\alpha_{1} \ln \mathrm{GDP}_{t}+\mu_{t} \text {. }
$$

On the contrary, Solow [26] argued that higher savings precede economic growth. This means that an increase in savings lead to a growth in the economy. Solow's assertion is mathematically presented as economic growth as a function of savings. Thus, it can be expressed econometrically as;

$$
\ln \mathrm{GDP}_{t}=\beta_{0}+\beta_{1} \ln \mathrm{GDS}_{t}+\varepsilon_{t} \text {. }
$$

where $\alpha_{0}$ and $\beta_{0}$ constants, and $\alpha_{1}$ and $\beta_{1}$ represent the slope coefficients and the degree of responsiveness of savings to economic growth and that of economic growth to savings respectively. $\mu_{t}$ and $\varepsilon_{t}$ are the stochastic disturbers in the respective equations.

\subsection{Variables Description and Expected Sign}

Gross domestic product (GDP) is the sum of all gross value added by all resident producers in the economy plus any product taxes minus subsidies not included in the value of the product. It is calculated without making deduction for depreciation of fabricated asset or depletion and degradation of natural resources. Economic growth is proxied by Gross domestic product at constant local currency unit. The data on economic growth were sourced from the World Development Indicators [27] spanning the period of 1972-2013. It is argued that an increase in income (economic growth) coupled with sound financial system in- 
creases the marginal propensity to save (MPS). Therefore, the expectation of the relationship between economic growth and gross domestic savings is positive.

Domestic savings include private and government savings. It is calculated as GDP less final consumption expenditure. Savings is proxied as gross domestic savings at current local currency unit. The data on domestic savings were extracted from the World Development Indicators [27] covering the period of 1972-2013. Harrod-Domer [28] explained that savings coupled with attitudinal, institutional and structural changes are key factors necessary to trigger economic growth. Romer [2] explicitly showed that higher rates of savings and hence capital accumulation can trigger a permanent increase in economic growth. Empirical work by Sajid and Sarfraz [12] in Pakistan has provided a solid justification for this assertion. Hence, the exact expected impact of gross domestic savings on economic growth is positive.

\subsection{Econometric Strategy}

\subsubsection{Cointegration Test}

After using Dickey-Fuller General Least Squares (DF-GLS) and Phillips-Perron (PP) tests to check the stationarity properties of the variables of interest, the study employed Johansen cointegration test to determine the long run equilibrium relationship gross domestic savings and economic growth. Johansen [29] cointegration techniques allow us to test and determine the number of cointegrating relationships between the non-stationary variables in the system using a maximum likelihood procedure. In making inferences about the number of cointegrating relationships, Johansen [29] [30] and Johansen and Juselius [31] proposed the use of two test statistics: the trace statistic and the maximum eigenvalue statistic. The trace statistic is determined using the following formula:

$$
\begin{gathered}
\beth_{\text {race }}=-T \sum_{i=r+1}^{n} \log \left(1-\beth_{i}\right) \quad r=0,1,2 \cdots n-1 \\
T=\text { number of observations } \\
\beth_{i}=\text { the } i^{\text {th }} \text { Eigenvalue. }
\end{gathered}
$$

The maximum eigenvalue statistics is determined using the following formula:

$$
\beth_{\max }=-T \log \left(1-\beth_{r+1}\right) \quad r=0,1,2 \cdots n-2, n-1 .
$$

The trace and maximum Eigen value statistics are compared with the critical values tabulated in Osterwald-Lenum [32]. Further, the Johansen procedure of conducting cointegration regression analysis provides a unified method for estimating and testing cointegrating relations in the framework of Vector Autoregressive (VAR) and Vector Error Correction (VEC) models.

\subsubsection{Vector Autoregressive Model}

If cointegration test reveals that variables are not cointegrated, the short run relationship between gross domestic savings and economic growth is determined with the aid of Granger causality procedure based on the Vector Autoregressive 
(VAR) model (Adebiyi [33]; Mohan [16]). A VAR model serves as a flexible approximation to the reduced form of any wide variety of simultaneous structural models. Besides, it allows causality to emerge the joint coefficients (F-statistic) of the lagged value of explanatory variables even where the variables are not cointegrated. In the study, the VAR model was expressed as:

$$
\begin{gathered}
\Delta \ln \mathrm{GDP}_{t}=\alpha_{0}+\sum_{i=1}^{r} \alpha_{1 i} \Delta \ln \mathrm{GDP}_{t-i}+\sum_{j=1}^{r} \alpha_{2 j} \Delta \ln \mathrm{GDS}_{t-j}+\mu_{t} \\
\Delta \ln \mathrm{GDS}_{t}=\beta_{0}+\sum_{i=1}^{s} \beta_{1 i} \ln \mathrm{GDP}_{t-i}+\sum_{j=1}^{s} \beta_{2 j} \Delta \ln \mathrm{GDS}_{t-j}+\varepsilon_{t}
\end{gathered}
$$

where $\mu_{t}$ and $\varepsilon_{t}$ are stochastic error terms, $r$, and $s$ denote the operational lag lengths determined by the Akaike Information and Schwartz-Bayesian criterion, $\Delta$ represents the difference operator, $\Delta \ln \mathrm{GDP}_{t}$ is the growth rate of GDP (defined as a change in the natural logarithm of GDP in period $t$ ). $\Delta \ln \mathrm{GDS}_{t}$ is the growth rate of gross domestic savings (defined as a change in the natural logarithm of GDS in period $t$ ). $\alpha_{1 i}$ and $\beta_{1 i}$ are the coefficients of GDP in Equations (6) and (7) respectively. $\alpha_{2 i}$ and $\beta_{2 i}$ are the coefficients of gross domestic savings in the same Equations (6) and (7) above respectively.

\subsubsection{Granger Causality Test}

As a robust check to the Vector Autoregressive (VAR) model with regards to gross domestic savings and economic growth, the pairwise Granger causality test was conducted to buttress or refute the results of any of the models. The pairwise Granger causality test examined a null hypothesis of no causal relationship between gross domestic savings and economic growth as against an alternative hypothesis of the existence of a causal relationship between gross domestic savings and economic growth.

\section{Results and Analysis of Econometric Estimation}

\subsection{Results of Unit Root Test}

The unit root test results are showed in Table 1 .

\begin{tabular}{|c|c|c|c|c|c|}
\hline \multirow{3}{*}{ Variable } & \multirow{2}{*}{\multicolumn{2}{|c|}{$\frac{\text { DF-GLS Test }}{\text { Level }}$}} & \multirow{2}{*}{\multicolumn{2}{|c|}{$\begin{array}{c}\text { Phillips-Perron Test } \\
\text { Level }\end{array}$}} & \multirow{3}{*}{ IO } \\
\hline & & & & & \\
\hline & No Trend & Trend & No Trend & Trend & \\
\hline $\operatorname{lnGDP}$ & 0.828 & -0.633 & 3.681 & -0.396 & \\
\hline \multirow[t]{2}{*}{$\operatorname{lnGDS}$} & 2.001 & -2.865 & 0.360 & -4.596 & \\
\hline & \multicolumn{2}{|c|}{ DF-GLS Test } & \multicolumn{2}{|c|}{ Phillips-Perron Test } & \\
\hline \multirow[t]{2}{*}{ Variable } & \multicolumn{2}{|c|}{ First Difference } & \multicolumn{2}{|c|}{ First Difference } & IO \\
\hline & No Trend & Trend & No Trend & Trend & \\
\hline$\Delta \operatorname{lnGDP}$ & $-2.561^{* *}$ & $-3.310^{* *}$ & $-4.127^{* * *}$ & $-5.884^{* * *}$ & $I(1)$ \\
\hline$\Delta \operatorname{lnGDS}$ & $-3.926^{* * *}$ & $-5.112^{* * *}$ & $-10.677^{* * *}$ & $-10.715^{* * *}$ & $I(1)$ \\
\hline
\end{tabular}

Table 1. Unit root test results.

Note: ${ }^{* * *}{ }^{* *}$ denote rejection of null hypothesis of $1 \%$ and $5 \%$ significance levels respectively. $\Delta$ is the first difference operator. 
The DF-GLS test results showed that economic growth and gross domestic savings were non-stationary at their levels when trended and not trended. These results were confirmed by the Phillips-Perron (PP) test results. Thus, the null hypothesis of non-stationarity of variables at their log levels cannot be rejected at the respective level of significance. This also suggests that the variables have unit roots at their level data proposing that the variables in question are non-stationary and as such any shock to those variables will not return to equilibrium. In the presence of unit root, the data need to be differenced to avoid misspecification in the causality test. The asymptotic distribution of the Granger causality test statistics is non-standard with non-stationarity (Mohan [16]). The study then proceeded to the first difference and found economic growth and gross domestic savings to be stationary at their first difference when trended and not trended as indicated by both DF-GLS and PP test results.

\subsection{Results of Cointegration Test}

The Johansen cointegration test was employed to examine the long run relationship between gross domestic savings and economic growth. Table 2 shows the results of the cointegration test.

From the cointegration test results in Table 2, both the trace and maximum eigenvalue tests showed that there was no cointegration between gross domestic savings and economic growth. This is because the trace and maximum eigenvalue statistics are less than the respective 5\% critical values. The absence of cointegration between gross domestic savings and economic growth is an indication that there exists no long run relationship between gross domestic savings and economic growth in Ghana. The absence of cointegration or long run equilibrium relationship is as result of the level of liberalisation in the Ghanaian financial market. High level of financial liberalisation reduces the average cost of savings across borders. Against the background of low deposit rate on savings in Ghana, surplus funds move across borders to earn high marginal returns. Therefore, the higher the liberalisation (openness) to get access to the international capital market, the weaker and insignificant the long run equilibrium relationship.

Table 2. Johansen test results for cointegration.

\begin{tabular}{ccc}
\hline \multicolumn{3}{c}{ Unrestricted Cointegration Rank Test (Trace) } \\
\hline None & Trace Statistic & 0.05 Critical Value (Trace) \\
At most 1 & 13.64039 & 15.49471 \\
Unrestricted Cointegration Rank Test (Maximum Eigenvalue) & 3.841466 \\
Hypothesized No. of CE (s) & Maximum Eigenvalue & 0.05 Critical Value (Max) \\
None & 13.37926 & 14.26460 \\
At most 1 & 0.261131 & 3.841466
\end{tabular}

Note: Trace indicates no cointegration at the 0.05 level. Maximum-Eigenvalue indicates no cointegration at the 0.05 level. 
The finding is similar to the study conducted by Ogoe [14] whereas the result contradicts the findings of Abu [18], Khan and Shahbaz [13], and El-Seoud [22].

\subsection{Results of VAR Lag Order Selection Criterion}

Since there existed no long run relationship between gross domestic savings and economic growth, a Vector Autoregression (VAR) was conducted to assess the short run relationship between the two variables concerned of the study. However, before the short run relationship was carried out, the VAR lag order selection criterion was undertaken to ascertain the extent of the lag length that was used in the estimation of the VAR model. The lag length of the VAR model was 1. This was based on the Akaike Information Criterion (AIC) and Final Prediction Error (FPE) method given that there were 42 observations. According to Liew [34] in an economic bulletin, the Akaike Information Criterion (AIC) and Final Prediction Error (FPE) are superior than the other criterion under study in the case of small sample (60 observations and below), in the manner that they chance of underestimation while maximizing the chance of recovering the true lag length. The results of the VAR lag order selection criterion are presented in Table 3.

\subsection{The Unrestricted VAR Presentation for Economic Growth and Gross Domestic Savings}

The cointegration test results conform to the VAR model because the model in question allows causality to emerge when variables are not cointegrated (Saltz [25]). Table 4 shows the VAR model for the two main variables of interest; the

Table 3. Results of VAR lag order selection criterion.

\begin{tabular}{ccccccc}
\hline \multicolumn{7}{c}{ Endogenous variables: LNGDP, LNGDS } \\
\hline Lag & LogL & LR & FPE & AIC & SBIC & HQ \\
\hline 0 & -91.48879 & NA & 0.367404 & 4.674440 & 4.758884 & 4.704972 \\
1 & 36.21830 & $236.2581^{*}$ & $0.000757^{*}$ & $-1.510915^{\star}$ & $-1.257583^{\star}$ & $-1.419318^{*}$ \\
2 & 40.17055 & 6.916445 & 0.000760 & -1.508528 & -1.086308 & -1.355866 \\
3 & 42.76800 & 4.285785 & 0.000819 & -1.438400 & -0.847292 & -1.224674 \\
4 & 42.88774 & 0.185606 & 0.001003 & -1.244387 & -0.484391 & -0.969597 \\
\hline
\end{tabular}

Note: ${ }^{*}$ indicates lag order selected by the criterion.

Table 4. Unrestricted VAR results for economic growth and gross domestic savings.

\begin{tabular}{ccc}
\hline Regressors & Economic Growth Equation & Savings Equation \\
\hline $\operatorname{lnGDP}_{t-1}$ & $0.968882^{\star * *}$ & 0.631626 \\
$\operatorname{lnGDS}_{t-1}$ & $0.010132^{\star * *}$ & $0.932507^{\star * *}$ \\
Constant & 0.590315 & -13.18600 \\
R-squared & 0.993652 & 0.974872 \\
Adjusted $R$-squared & 0.993334 & 0.973615 \\
F-statistic & 3130.411 & 775.9206 \\
\hline
\end{tabular}

Note: ${ }^{* *}$ denotes significance at $1 \%$ level. 
first difference of economic growth and the first difference of gross domestic savings.

The results showed statistical significance of the coefficients of the exogenous variables in economic growth equation. With the coefficients of 0.968882 and 0.010132 , a $1 \%$ increase in economic growth and gross domestic savings in the previous year will cause the current rate of economic growth to rise by $0.97 \%$ and $0.01 \%$ respectively. Thus, a change in gross domestic savings has a significant positive impact on economic growth and therefore it is relevant to policy decisions on sustaining the economic growth. As it was expected, the constant term of economic growth was positive. This is because the aggregate demand curve theoretically has positive intercept. The $R$-squared value of $0.993652 \mathrm{im}$ plies that about $99 \%$ of the variation in the growth rate of the Ghana economy is explained by the independent variables in the model.

However, the results differed when gross domestic saving was endogenised. The coefficient of the lag of economic growth possessed its expected positive sign but it was not statistically significant with respect to its dynamic relationship with gross domestic savings. It was observed from the results that, a change in gross domestic savings at lag one has a significant effect on changes in gross domestic savings. Thus, a percentage change in the value of gross domestic savings a period ago results in a $0.93 \%$ change in gross domestic savings currently. Stated in another sense, an increase in the value of gross domestic savings a year ago leads to an increase in gross domestic savings in the current period. In addition, the intercept of the growth rate of savings has its expected negative sign since the saving function theoretically intercepts the $Y$-axis negatively. The negative constant term means that people dissave when they earn no income. The $R$-squared value of 0.974872 indicates that $97.5 \%$ of the deviation in the gross domestic savings is influenced by variations in the independent variables in the model.

\subsection{Results of VAR Granger Causality Test}

In order to verify the direction of causality between gross domestic savings and economic growth in Ghana, a post VAR Granger causality was conducted. Table 5 represents the post VAR estimation results for testing the Granger causality Wald test for the two equations; thus the first difference of the gross domestic savings and economic growth.

The study realized that the null hypothesis that the first difference of gross domestic savings does not Granger cause the first difference of economic growth

Table 5. VAR Granger causality test results for economic growth and gross domestic savings.

\begin{tabular}{cccc}
\hline Null Hypothesis & Chi-Squared & $p$-Value & Direction of Causality \\
\hline lnGDS does not Granger cause lnGDP & 6.037663 & $0.0140^{\star *}$ & Causality \\
lnGDP does not Granger cause lnGDS & 1.029360 & 0.3103 & No Causality \\
\hline
\end{tabular}

Note: ${ }^{\star *}$ represents rejection of the null hypothesis at 5\% level. 
was rejected, given a p-value of 0.0140 . Thus, lags in gross domestic savings Granger cause movements in economic growth rate at $5 \%$ level of significance suggesting gross domestic savings is a better predictor of economic growth in Ghana.

In contrast, a look at the results of the test for the second equation revealed unrelated outcomes. The post VAR Granger causality accepted the null hypothesis that the coefficient on the lag of the economic growth at the first difference of the gross domestic savings equation is zero. The implication is that there exists no causality from the economic growth to gross domestic savings. This was evidenced from the $p$-value of 0.3103 . Thus, past movements in Ghana's economic growth rate do not Granger cause the variations in her gross domestic savings.

The results confirm the short run VAR results that, in Ghana, there exists a unidirectional causation between gross domestic savings and economic growth of which the direction of causation runs from gross domestic savings to economic growth. This finding upholds the Romer [2] and the Harrod-Domer model. However, a bi-directional line of causation was found by Mavrotas and Kelly [35], Dawit [36], and Ogoe [14] to exist between gross domestic savings and economic growth in Sri Lanka, Ethiopia, and Ghana respectively.

\subsection{Pairwise Granger Causality Test Results}

The pairwise Granger causality test was also conducted to provide a justification or otherwise for the VAR results above. Table 6 demonstrates the results of the Granger causality test conducted.

From Table 6, it was evident that null hypothesis that growth rate of domestic savings does not Granger cause economic growth was rejected at $10 \%$ level of significance. This means that changes in gross domestic savings explain the variations in economic growth rate in Ghana. However, different observation was made with gross domestic savings as the endogenous variable. The null hypothesis of no causality running from economic growth to gross domestic savings was not rejected at any of the levels of significance. The study, therefore, finds a unidirectional causality between gross domestic savings and economic growth in Ghana. The pairwise Granger causality test results justify the VAR Granger causality test results that there exists a unidirectional causality running from gross domestic savings to economic growth. The finding contradicts the results of Odhiambo [23], Abu [18], Khan and Shahbaz [13], Sothan [24], and Adeleke [20].

Table 6. Pairwise Granger causality test results.

\begin{tabular}{cccc}
\hline Null Hypothesis: & Obs. & F-Statistic & $p$-Value \\
\hline lnGDS does not Granger Cause lnGDP & 41 & 2.28655 & 0.0963 \\
$\operatorname{lnGDP}$ does not Granger Cause lnGDS & & 0.38909 & 0.7616 \\
\hline
\end{tabular}




\subsection{Impulse Response Function}

The impulse response function, according to Sims and Zha [37] displays the dynamic responses of the exogenous variables compared with the time of variation of the endogenous variables. The panel Figure 1 presents the impulse response function graph for the variables employed in the VAR model.

A look at the panel revealed virtually no responses of gross domestic savings to the shocks in Ghanaian economic growth. However, it was found that the shocks in gross domestic savings had a permanent significant effect on the economic growth. This implies that a rise in gross domestic savings causes a significant effect on the economic growth. Thus, the results confirm the unidirectional causality running from gross domestic savings to economic growth.

\section{Conclusion and Policy Implications}

The study was intended to investigate the relationship between gross domestic savings and economic growth in Ghana; with the specific objective of finding whether there exists a long run relationship between them, and it was also intended to ascertain the direction of causality between the two running actors in the study over the period of 1972 to 2013. The study employed Johansen cointegration test to reveal no long run relationship between gross domestic savings and economic growth in Ghana. This necessitated the usage of the VAR technique to estimate the short

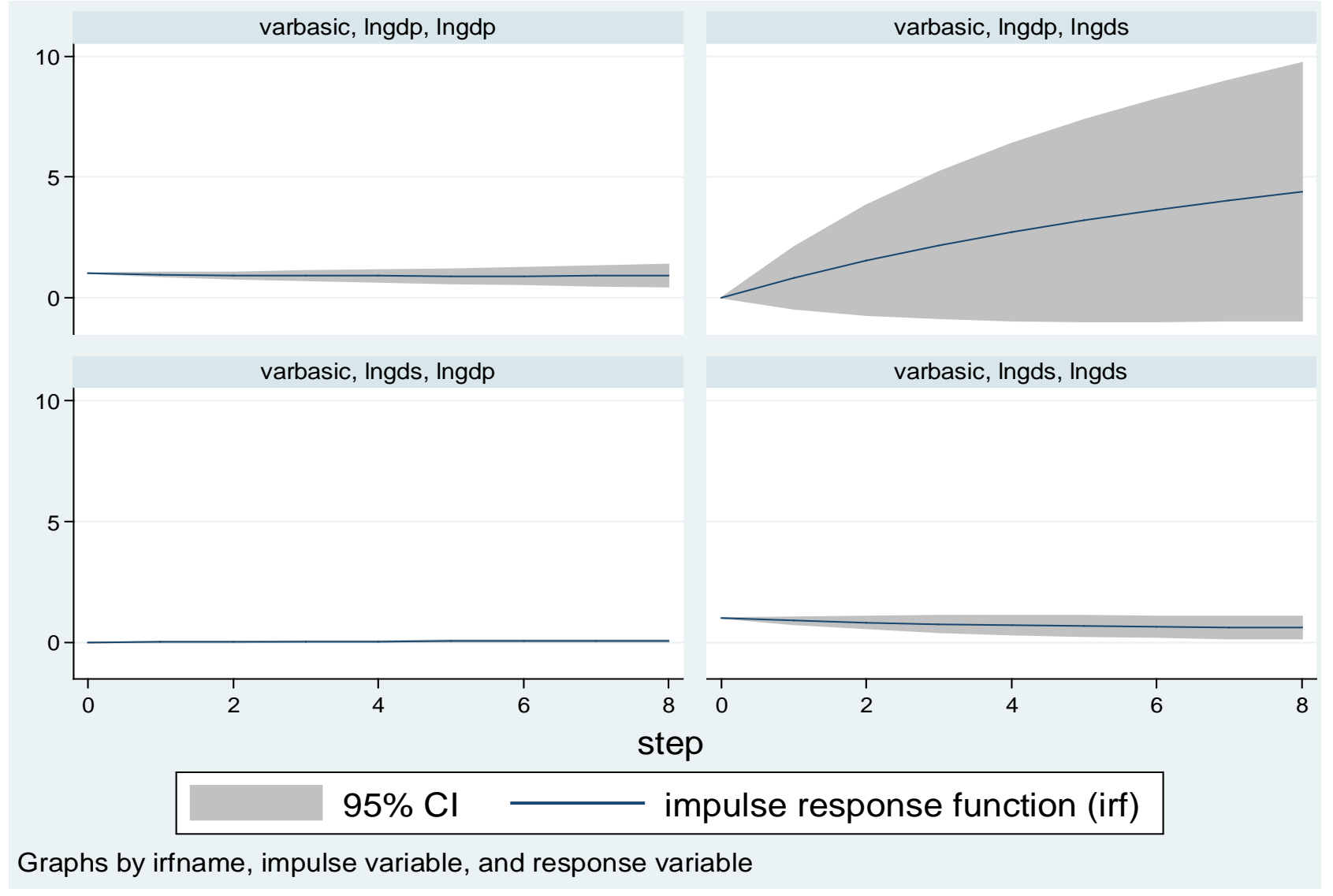

Figure 1. Impulse response function. 
run relationships. The finding was that there exists a unidirectional line of causation running from gross domestic savings to economic growth in Ghana. This empirical evidence has some policy implications. In view of this, the study recommends the following policies to stakeholders so as to accelerate savings and stimulate economic growth.

Incumbent and future governments must have "target savings" as a national agenda and policy. The country must have a specified amount or threshold that successive government must strive to attain if the country wishes to grow. This can be achieved by increasing the deposit rate. This is because the real interest rate on savings is a key ingredient for savings, investment and economic growth for that matter. So the regulatory body of the bank of Ghana must ensure the rise and abolishment of financial constraint on savings. This abolishment will increase the average efficiency of investment, the level of income will increase and savings will rise (see McKinnon and Shaw [38]). The central bank can make this happen through its monetary policy instruments; it carries out in the economy through the commercial banks.

The current deposit rate stands at $5 \%$ per annum. This infinitesimal rate on deposits serves as a disincentive to savers and potential savers since the real returns on savings decline against the background of the high inflation rate. In view of this, rational economic agents and those at the surplus unit do not consider savings as a viable option and so diversify their portfolio to hold assets with high returns. It is strongly recommended therefore that the central bank will use the monetary policy instruments to influence and advise the commercial banks on the need to peg the deposit rate relatively higher at least equal or little above the existing interest rate. This is because the deposit rate is the opportunity cost of money demand for other purposes. So, the higher the deposit rate, the higher the opportunity cost. Economic agents would rationally minimise the cost by saving more to boost investment and growth.

\section{References}

[1] Solow, R.M. and Swan, T.W. (1956) Economic Growth and Capital Accumulation. Economic Record, 32, 334-361. https://doi.org/10.1111/j.1475-4932.1956.tb00434.x

[2] Romer, P. (1986) Increasing Returns and Long-Run Growth. Journal of Political Economy, 94, 1002-1037. https://doi.org/10.1086/261420

[3] Jappelli, T. and Pagano, M. (1994) Savings, Growth and Liquidity Constraint. Quarterly Journal of Economics, 109, 83-109. https://doi.org/10.2307/2118429

[4] Carroll, C.D. and Weil, D.N. (1994) Saving and Growth: A Reinterpretation. Carnegie-Rochester Conference Series on Public Policy, Vol. 40, 133-192. https://doi.org/10.1016/0167-2231(94)90006-X

[5] Sinha, D. and Sinha, T. (1998) Cart before the Horse? The Saving-Growth Nexus in Mexico. Economics Lectures, 6, 43-47.

[6] Carroll, C.D., Overland, J. and Weil, D.N. (2000) Saving and Growth with Habit Formation. The American Economic Reviews, 90, 341-355.

https://doi.org/10.1257/aer.90.3.341

[7] Rodrik, D. (2000) Saving Transitions. The World Bank Economic Review, 14, 481507. https://doi.org/10.1093/wber/14.3.481 
[8] Lewis, W.A. (1955) Theory of Economic Growth. Allen and Unwin Ltd., London.

[9] Levine, R. and Renelt, D. (1992) A Sensitivity Analysis of Cross Countries Growth Regression. American Economic Review, 82, 942-963.

[10] Mankiw, N.G., Romer, D. and Weil, D.N. (1992) A Contribution to Empirics of Economic Growth. Quarterly Journal of Economic, 107, 681-712. https://doi.org/10.2307/2118477

[11] Alguacil, M., Cuadros, A. and Orts, V. (2004) Does Saving Really Matter for Growth? Mexico (1970-2000). Journal of International Development, 16, 281-290. https://doi.org/10.1002/jid.1075

[12] Sajid, G.M. and Sarfraz, M. (2008) Savings and Economic Growth in Pakistan: An Issue of Causality. Pakistan Economic and Social Review, 46, 17-36.

[13] Shahbaz, M.Q. and Khan, R.E.A. (2010) Old Wine in New Bottles: Saving-Growth Nexus: Innovative Accounting Technique in Pakistan. Theoretical and Applied Economics, 17, 548.

[14] Ogoe, E. (2009) An Econometric Analysis of the Causal Relationship between Gross Domestic Savings and Economic Growth in Ghana (1961-2008). Master's Thesis, The Department of Economics, Kwame Nkrumah University of Science and Technology, Kumasi.

[15] Deaton, A. and Paxson, C. (2000) Growth and Saving among Individuals and Households. Review of Economics and Statistics, 82, 212-225. https://doi.org/10.1162/003465300558740

[16] Mohan, R. (2006) Causal Relationship between Savings and Economic Growth in Countries with Different Income Levels. Economics Bulletin, 5, 1-12.

[17] Lean, H.H. and Song, Y. (2009) The Domestic Savings and Economic Growth Relationship in China. Journal of Chinese Economic and Foreign Trade Studies, 2, 5-17. https://doi.org/10.1108/17544400910934315

[18] Abu, N. (2010) Saving-Economic Growth Nexus in Nigeria, 1970-2007: Granger Causality and Cointegration Analyses. Review of Economics and Business Studies, 3, 93-104.

[19] Bankole, A.S. and Fatai, B.O. (2013) Relationship between Savings and Economic Growth in Nigeria. The Social Sciences, 8, 224-230.

[20] Adeleke, A.M. (2014) Saving-Growth Nexus in an Oil-Rich Exporting Country: A Case of Nigeria. Management Science and Engineering, 8, 72-78.

[21] Alomar, I. (2013) Economic growth and savings in GCC: A Cointegration and Causal Relationship Analysis. International Journal of Humanities and Social Science, 3, 213-218.

[22] El-Seoud, M.S. (2014) Testing the Relationship between Private Savings and Economic Growth: Case of Bahrain. Global Journal of Commerce and Management Perspective, 1, 38-44.

[23] Odhiambo, N.M. (2009) Savings and Economic Growth in South Africa: A Multivariate Causality Test. Journal of Policy Modelling, 31, 708-718. https://doi.org/10.1016/j.jpolmod.2009.04.001

[24] Sothan, S. (2014) Causal Relationship between Domestic Saving and Economic Growth: Evidence from Cambodia. International Journal of Economics and Finance, 6, 213. https://doi.org/10.5539/ijef.v6n9p213

[25] Saltz, I.S. (1999) An Examination of the Causal Relationship between Savings and Economic Growth in the Third World. Journal of Economics and Finance, 23, 90-98. 
[26] Solow, R.M. (1956) A Contribution to the Theory of Economic Growth. The Quarterly Journal of Economics, 70, 65-94. https://doi.org/10.2307/1884513

[27] World Bank (2013) World Economic Indicators Ghana Country Data.

[28] Domer, E.D. (1946) Capital Expansion, Rate of Growth, and Employment. Econometrica, 14, 137-147.

[29] Johansen, S. (1988) Statistical Analysis of Cointegration Vectors. Journal of Economic Dynamics and Control, 12, 231-254. https://doi.org/10.1016/0165-1889(88)90041-3

[30] Johansen, S. (1991) Statistical Analysis of Cointegration Vectors. Journal of Dynamics and Control, 12, 232-254.

[31] Johansen, S. and Juselius, K. (1990) Maximum Likelihood Estimation and Inference on Cointegration with Applications to the Demand for Money. Oxford Bulletin of Economics and Statistics, 52, 169-210. https://doi.org/10.1111/j.1468-0084.1990.mp52002003.x

[32] Osterwald-Lenum, M. (1992) A Note with Quantiles of the Asymptotic Distribution of the Maximum Likelihood Cointegration Rank Test Statistics1. Oxford Bulletin of Economics and statistics, 54, 461-472. https://doi.org/10.1111/j.1468-0084.1992.tb00013.x

[33] Adebiyi, M.A. (2005) Savings-Growth Relationship in Nigeria. An Empirical Evidence. African Review of Money, Finance and Banking, 29, 159-178.

[34] Liew, V.K.S. (2004) Which Lag Length Selection Criteria Should We Employ? Economics Bulletin, 3, 1-9.

[35] Mavrotas, G. and Kelly, R. (2001) Old Wine in New Bottles: Testing Causality between Savings and Growth. The Manchester School, 69, 97-105. https://doi.org/10.1111/1467-9957.69.s1.6

[36] Dawit, S. (2005) Causal Relationship between Economic Growth and Gross Domestic Savings: Case of Ethiopia. Department of Economics, Addis Ababa University, Addis Ababa.

[37] Sims, C.A. and Zha, T. (1999) Error Bands for Impulse Responses. Econometrica, 67, 1113-1155. https://doi.org/10.1111/1468-0262.00071

[38] McKinnon, R. and Shaw, E. (1973) Financial Deepening in Economic Development. Brookings Institution, Washington DC. 
Submit or recommend next manuscript to SCIRP and we will provide best service for you:

Accepting pre-submission inquiries through Email, Facebook, LinkedIn, Twitter, etc. A wide selection of journals (inclusive of 9 subjects, more than 200 journals)

Providing 24-hour high-quality service

User-friendly online submission system

Fair and swift peer-review system

Efficient typesetting and proofreading procedure

Display of the result of downloads and visits, as well as the number of cited articles Maximum dissemination of your research work

Submit your manuscript at: http://papersubmission.scirp.org/

Or contact tel@scirp.org 